\title{
Untreated Childhood Anaplastic Astrocytoma
}

National Cancer Institute

\section{Source}

National Cancer Institute. Untreated Childhood Anaplastic Astrocytoma. NCI Thesaurus.

Code C115919.

A finding of anaplastic astrocytoma in childhood that has not been treated. 